\title{
Analisis Performansi Sistem Klasifikasi Kanker Kulit Menggunakan Convolutional Neural Network
}

\section{Performance Analysis of Skin Cancer Classification System Using Convolutional Neural Network}

\author{
Dian Ayu Nurlitasari1)*, Rita Magdalena2), \& R Yunendah Nur Fu'adah3) \\ 1)Prodi $S 1$ Teknik Telekomunikasi, Fakultas Teknik Elektro, Universitas Telkom, Indonesia \\ 2)Prodi $S 1$ Teknik Telekomunikasi, Fakultas Teknik Elektro, Universitas Telkom, Indonesia \\ 3)Prodi S1 Teknik Telekomunikasi, Fakultas Teknik Elektro, Universitas Telkom, Indonesia
}

*Coresponding Email: dianayun@student.telkomuniversity.ac.id

\begin{abstract}
Abstrak
Kanker kulit adalah salah satu kanker ganas yang banyak ditemukan di Indonesia dan dapat menyebabkan kematian. Diagnosis kanker kulit dilakukan secara manual oleh dokter kulit melalui proses biopsi dan mikroskopis, namun proses ini memakan waktu lama dan membawa risiko kecelakaan selama proses biopsi. Sedangkan diagnosis dini menunjukkan lebih dari 90\% dapat disembuhkan, dan diagnosis yang terlambat menunjukkan kurang dari 50\% dapat disembuhkan.Pada Tugas Akhir ini diusulkan metode Convolutional Neural Network (CNN) menggunakan arsitektur Alexnet untuk mengklasifikasikan kanker kulit. Eksperimen dilakukan dengan menggunakan dataset yang diperoleh dari dataset International Skin Imaging Collaboration (ISIC) sebanyak 4000 citra kondisi kanker kulit dermatofibroma, melanoma, nevus pig-mentosus, dan karsinoma sel skuamosa, yang terdiri dari 1000 citra di setiap kelas. Dataset tersebut akan digunakan sebagai data latih dan data validasi dengan distribusi persentase data latih $80 \%$ dan data validasi 20\%. Jadi jumlah data latih yang digunakan adalah 3200 citra kanker kulit. Sedangkan jumlah data validasi yang digunakan adalah 800 citra. Parameter terbaik yang digunakan dalam sistem klasifikasi kanker kulit ini antara lain menggunakan ukuran citra 64x64 piksel pada proses pre-processing, menggunakan Adam optimizer, learning rate 0,0001, epoch 20 dan batch size 16. Hasil pengujian menunjukkan bahwa sistem dapat mengklasifikasikan kulit kanker menurut kelasnya, dengan tingkat akurasi 99,50\%, nilai presisi dan recall 99,75\%, nilai f1-score 99,50\%, dan nilai loss 0,0223. Berdasarkan hasil kinerja sistem, menunjukkan bahwa model yang dibuat menjanjikan untuk menjadi alat deteksi dini kanker kulit oleh dokter kulit dan dapat membantu mengurangi resiko keterlambatan diagnosis dini.
\end{abstract}

Kata kunci: Alexnet, Convolutional Neural Network, Kanker kulit.

Abstract
Skin cancer is one of the most common malignant cancers in Indonesia and can cause death. Skin cancer
diagnosis is done manually by a dermatologist through a biopsy and microscopic process. However, this process
takes a long time and carries the risk of accidents during the biopsy process. While early diagnosis shows more
than 90\% can be cured, while late diagnosis shows less than 50\% can be cured. In this final project, the
Convolutional Neural Network (CNN) method using Alexnet architecture are proposed to classify skin cancer.
Experiments were carried out using a dataset obtained from the International Skin Imaging Collaboration
(ISIC) dataset of 4000 images of skin cancer conditions dermatofibroma, melanoma, nevus pigmentosus, and
squamous cell carcinoma, consisting of 1000 images in each class. The dataset will be used as training data
and validation data with the percentage distribution of $80 \%$ training data and $20 \%$ validation data. So the
number of training data used is 3200 skin cancer images. While the number of validation data used is 800
images. The best parameters used in this skin cancer classification system include using a $64 x 64$ pixel image


Nurlitasari, D. A, Magdalena, R, Fu'adah, R. Y. N. Analisis Performansi Sistem Klasifikasi Kanker Kulit Menggunakan Convolutional Neural Network

resizing in the pre-processing process, using the Adam optimizer, learning rate 0.0001, epoch 20 and batch size 16. The test results show that the system can classify skin cancer according to its class, with an accuracy rate of $99.50 \%$, a precision and recall value of $99.75 \%$, an 11 -score value of $99.50 \%$, and a loss value of 0.0223 . Based on the results of the system performance, it shows that the model made promises to be an early detection tool for skin cancer by dermatologists and can help reduce the risk of delaying early diagnosis.

Keywords: Skin cancer, Convolutional Neural Network, Alexnet.

How to Cite: Nurlitasari, D. A, Magdalena, R, Fu'adah, R. Y. N. (2022). Analisis Performansi Sistem Klasifikasi Kanker Kulit Menggunakan Convolutional Neural Network. JESCE (Journal of Electrical and System Control Engineering). 4 (1): 91-99 


\section{PENDAHULUAN}

Kanker kulit adalah salah satu kanker ganas yang banyak ditemukan di Indonesia dan dapat menyebabkan kematian. Pada tahun 2018, tercatat sebanyak 6.170 kasus kanker kulit nonmelanoma dan 1.392 kasus kanker kulit melanoma (ICCC, 2020). Hal ini dikarenakan zat-zat pada makanan yang dapat menjadi racun pada tubuh manusia dan efek global warming. Selain itu, intensitas seringnya terpapar radiasi sinar ultraviolet dari matahari juga merupakan salah satu penyebab utama kanker kulit. Radiasi matahari yang masuk ke bumi seharusnya diserap oleh lapisan ozon sebanyak 9399\%. Seiring berkembangnya jaman, kapasitas ozon semakin menipis menyebabkan sinar Ultra Violet (UV) yang masuk ke bumi semakin besar hingga dapat menyebabkan penyakit kanker kulit bagi manusia (Foeady, 2019).

Umumnya, diagnosa kanker kulit dilakukan oleh dokter dengan proses Biopsi dan Mikroskopis. Proses Biopsi dilakukan dengan cara mengambil potongan kecil dari bagian sel kanker untuk kemudian dicek dan diuji secara mendetail oleh dokter atau ahli dermatologis. Dengan menggunakan teknik pengujian ini membutuhkan waktu yang cukup lama untuk seorang ahli dermatologis dan memiliki resiko kecelakaan pada saat proses Biopsi. Dari penelitian yang telah dilakukan, diagnosa dini kanker kulit menunjukkan lebih dari 90\% dapat disembuhkan dan jika terlambat mendiagnosa menunjukkan kurang dari 50\% dapat disembuhkan (Munthe,
2018). Oleh karena itu, jika proses diagnosa dapat dilakukan lebih dini akan dapat membantu mengurangi resiko keterlambatan diagnosa pada kanker kulit.

Sebelumnya telah dilakukan penelitian oleh Mustika Mentari dengan judul Deteksi Kanker Kulit Melanoma dengan Linear Discriminant AnalysisFuzzy k-Nearest Neighbour Lp-Norm (Mustika, 2016) dengan menggunakan 200 data citra dermoscopy yang beragam untuk dua jenis kanker kulit yaitu melanoma dan non-melanoma dengan nilai akurasi 72\%. Kemudian penelitian oleh Tama Loy Dennis Munthe dengan judul Klasifikasi Citra Kanker Kulit Berdasarkan Tingkat Keganasan Kanker pada Melanosit menggunakan Deep Convolutional Neural Network (Tama, 2018) dengan data latih yang digunakan sebanyak 1500 citra yang terdiri atas 3 kelas kategori yaitu, nevus, melanoma in situ dan malignant melanoma dengan tingkat akurasi sebesar 84\%. Selanjutnya dilakukan penelitian tentang klasifikasi kanker kulit menggunakan Deep Learning dan Transfer Learning (Khalid, 2018). Pada penelitian tersebut, metode Deep Convolutional Neural Network diterapkan untuk mengklasifikasikan gambar kanker kulit. Dengan menerapkan klasifikasi AlexNet dan mengganti lapisan terakhir dengan softmax untuk mengklasifikasikan tiga lesi berbeda yaitu melanoma, common nevus, dan atypical nevus. Hasil akurasi yang diperoleh pada penelitian tersebut adalah 98,61\%.

Berdasarkan penelitian-penelitian 
yang telah dilakukan sebelumnya, pada penelitian ini dibuat sistem klasifikasi kanker kulit menggunakan metode Convolutional Neural Network dengan menggunakan arsitektur AlexNet. Arsitektur Alexnet dipilih karena Alexnet mampu mengurangi tingkat kesalahan dari 5 pemenang teratas lainnya dari $26 \%$ menjadi $15,3 \%$ dengan lapisan yang lebih sedikit. Selain jumlah layer yang sedikit, penggunaan relu pada arsitektur alexnet dapat membuat proses pelatihan lebih cepat dari model CNN biasa. Klasifikasi yang dilakukan menggunakan dataset yang didapat dari kumpulan data International Skin Imaging Collaboration (ISIC) dengan jumlah kelas kategori sebanyak empat kelas yaitu dermatofibroma, melanoma, nevus pigmentosus, dan squamous cell carcinoma.

\section{METODE PENELITIAN}

Convolutional Neural Network adalah bagian dari deep learning yang efektif digunakan untuk analisa gambar visual, deteksi objek atau image. Convolutional Neural Network terdiri atas sekumpulan lapisan yang dapat dikelompokkan berdasarkan fungsinya (Munthe, 2018).

CNN terdiri atas dua bagian besar, yaitu feature extraction layer dan classification layer. Pada bagian Feature Extraction Layer terdiri atas beberapa bagian, yaitu Convolutional Layer dengan aktivasi ReLU, dan Pooling layer yang berfungsi sebagai layer ekstrasi ciri dan layer terhubung penuh dengan aktivasi softmax sebagai layer klasifikasi. Di dalam Feature Extraction
Layer terjadi proses encoding sebuah input berupa images menjadi features berupa angka-angka yang merepresentasikan images tersebut. Pengklasifikasian tiap neuron yang telah diekstraksi pada layer sebelumnya dilakukan pada Classification Layer. Layer ini terdiri atas flatten, fully connected layer, dan softmax (Munthe, 2018).

Dataset diperoleh dari dari kumpulan data International Skin Imaging Collaboration (ISIC) berupa citra digital yang terdiri dari empat kategori penyakit kanker kulit yaitu dermatofibroma, melanoma, nevus pigmentosus, dan squamous cell carcinoma.

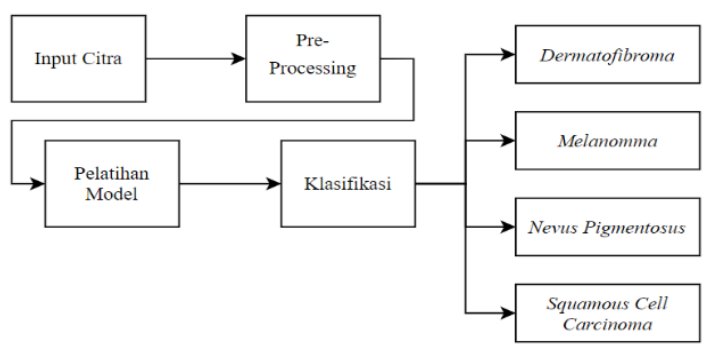

Gambar 2. Diagram Blok Sistem

Secara umum, sistem yang dirancang dan diimplementasikan pada penelitian ini ditunjukkan pada Gambar 2. Sistem yang dirancang dan diimplementasikan terdiri atas empat tahap utama, yaitu input citra, pre-processing, pelatihan model, dan klasifikasi. Pada preprocessing dilakukan pengolahan citra terhadap citra kulit yang didapat dari proses input agar sesuai dengan kebutuhan penelitian. Kemudian dilanjutkan pada tahap pelatihan model, sistem akan melakukan pengenalan terhadap citra kulit melalui dua tahap yaitu tahap latih dan tahap validasi untuk selanjutnya diklasifikan 
sesuai dengan kelasnya. Proses klasifikasi menggunakan arsitektur Alexnet. Secara garis besar, model Alexnet yang digunakan pada penelitian ini digambarkan pada Gambar 3.

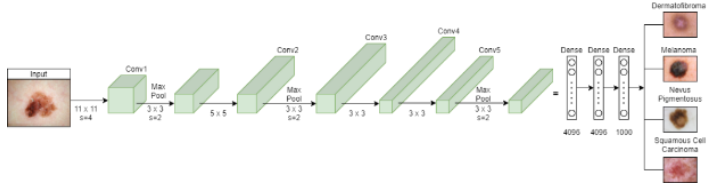

Gambar 3. Model Arsitektur Alexnet

Untuk arsitektur Alexnet memiliki delapan layer yang terbagi menjadi lima convolutional layer dan tiga fully connected layer. Input gambar yang digunakan adalah citra dengan ukuran $64 \times 64$ piksel. Tabel 1 menunjukkan layer type dan output shape yang digunakan pada setiap layer.

Tabel 1. Hasil Pengujian Optimizer

\begin{tabular}{cc}
\hline Layer (Type) & Output Shape \\
\hline Convolutional & $16,16,96$ \\
\hline Max Pooling & $8,8,96$ \\
\hline Convolutional & $8,8,256$ \\
\hline Max Pooling & $4,4,256$ \\
\hline Convolutional & $4,4,384$ \\
\hline Convolutional & $4,4,384$ \\
\hline Convolutional & $4,4,256$ \\
\hline Max Pooling & $2,2,256$ \\
\hline Flatten & 1024 \\
\hline Dense & 4096 \\
\hline Dense & 4096 \\
\hline Dense & 1000 \\
\hline Softmax & 4
\end{tabular}

\section{HASIL DAN PEMBAHASAN}

Data yang digunakan sebanyak 4000 citra yang terdiri dari 1000 citra pada setiap kelasnya. Kemudian data dari setiap kelas tersebut dibagi menjadi 3200 data latih dan 800 data validasi. Pengujian sistem dilakukan menggunakan parameter-parameter pengujian yang telah ditentukan. Skenario pengujian pertama dilakukan pengujian terhadap beberapa optimizer agar didapatkan optimizer terbaik untuk digunakan dalam sistem klasifikasi kanker kulit yang dibuat. Adapun beberapa optimizer yang digunakan dalam skenario pengujian optimizer ini adalah Adam, Nadam, RMSprop, dan SGD. Pengujian dilakukan dengan menggunakan parameter yang ditentukan, yaitu menggunakan epoch 50, learning rate 0,001 dan batch size 32 . Hasil pengujian menunjukkan hasil seperti pada Tabel 2.

Tabel 2. Hasil Pengujian Optimizer

\begin{tabular}{ccc}
\hline Optimizer & $\begin{array}{c}\text { Akurasi } \\
\mathbf{( \% )}\end{array}$ & Loss \\
\hline SGD & 97.87 & 0.0848 \\
\hline RMSprop & 78.00 & 0.3576 \\
\hline Adam & 99.12 & 0.1512 \\
\hline Nadam & 22.88 & 0.1388 \\
\hline Hasil & pengujian & optimizer
\end{tabular}

menunjukkan bahwa pada penelitian ini penggunaan optimizer Adam mendapatkan nilai akurasi terbaik, yaitu sebesar 99,12\% dan nilai loss sebesar 0,1512. Hal ini karena dengan menggunakan model Alexnet dan dataset yang digunakan, optimizer Adam adalah yang paling cocok digunakan sehingga mendapatkan nilai akurasi yang paling optimal.

Skenario kedua dilakukan pengujian untuk mengetahui pengaruh penggunaan learning rate. Pengujian menggunakan parameter optimizer terbaik yang didapat dari pengujian sebelumnya, serta parameter lain yg telah ditentukan yaitu epoch 50, dan batch size 32. Pencarian nilai learning 
rate terbaik dilakukan dengan menggunakan nilai $0,01,0,001$, dan 0,0001 . Hasil pengujian menunjukkan hasil seperti pada Tabel 3.

Tabel 3. Hasil Pengujian Learning Rate

\begin{tabular}{ccc}
\hline $\begin{array}{c}\text { Learning } \\
\text { Rate }\end{array}$ & $\begin{array}{c}\text { Akurasi } \\
\text { (\%) }\end{array}$ & Loss \\
\hline 0.01 & 26.37 & 0.085 \\
\hline 0.001 & 97.37 & 0.1075 \\
\hline 0.0001 & 99.00 & 0.1386 \\
\hline
\end{tabular}

Hasil pengujian learning rate menunjukkan bahwa pada penelitian ini, penggunaan learning rate 0,0001 mendapatkan nilai akurasi terbaik dari nilai learning rate lainnya, yaitu sebesar 99\% dan nilai loss sebesar 0,0853. Hal ini karena semakin kecil nilai learning rate, maka sistem akan semakin teliti dalam melakukan identifikasi, sehingga nilai akurasi semakin mendekati optimal. Sedangkan semakin besar nilai learning rate, maka ketelitian sistem dalam mengidentifikasi semakin kecil, sehingga sulit untuk mencapai nilai akurasi optimal.

Skenario ketiga dilakukan pengujian untuk mengetahui pengaruh penggunaan epoch. Pengujian menggunakan parameter-parameter terbaik yang didapat dari pengujian sebelumnya yaitu optimizer Adam dan learning rate 0.0001 , serta parameter lain yg telah ditentukan yaitu batch size 32. Adapun beberapa nilai epoch yang digunakan dalam skenario pengujian ini adalah 5, 10, 15, dan 20. Hasil pengujian menunjukkan hasil seperti pada Tabel 4 .
Tabel 4. Hasil Pengujian Epoch

\begin{tabular}{ccc}
\hline Epoch & $\begin{array}{c}\text { Akurasi } \\
\text { (\%) }\end{array}$ & Loss \\
\hline 5 & 93.37 & 0.2069 \\
\hline 10 & 98.62 & 0.0347 \\
\hline 15 & 98.75 & 0.0385 \\
\hline 20 & 99.25 & 0.0361 \\
\hline
\end{tabular}

Berdasarkan Tabel 4 diketahui bahwa pada penelitian ini, penggunaan nilai epoch terbaik adalah 20 dengan nilai akurasi tertinggi yaitu sebesar 99,25\% dan nilai loss didapatkan sebesar 0,0361. Hal ini dikarenakan dengan menggunakan model Alexnet dan dataset yang digunakan, semakin banyak jumlah epoch maka akan semakin akurat identifikasi citra. Sebaliknya, semakin sedikit jumlah epoch maka akan semakin kecil tingkat akurasi identifikasi citra, namun nilai epoch terbaik juga bergantung pada penggunaan batch size.

Skenario keempat dilakukan pengujian untuk mencari nilai bacth size terbaik untuk digunakan dalam sistem klasifikasi kanker kulit. Pengujian dilakukan dengan menggunakan parameter-parameter terbaik yang telah didapatkan pada skenario pengujian sebelumnya. Sehingga parameter yang digunakan adalah menggunakan optimizer Adam, learning rate 0,0001, dan epoch 20. Adapun nilai bacth size yang digunakan dalam pengujian ini adalah $8,16,32$, dan 64. Tabel 5 berikut ini menunjukkan perbandingan hasil performansi pengujian batch size.

Tabel 5. Hasil Pengujian Batch Size

\begin{tabular}{ccc}
\hline Batch Size & $\begin{array}{c}\text { Akurasi } \\
\text { (\%) }\end{array}$ & Loss \\
\hline 8 & 97.12 & 0.1023 \\
\hline
\end{tabular}




\begin{tabular}{lll}
\hline 16 & 99.50 & 0.0223 \\
\hline 32 & 99.25 & 0.0361 \\
\hline 64 & 98.87 & 0.0263 \\
\hline
\end{tabular}

Hasil pengujian menunjukkan bahwa pada penelitian ini, penggunaan batch size 16 mendapatkan hasil akurasi terbaik, yaitu sebesar 95,50\% dan nilai loss sebesar 0,0223. Hal ini dikarenakan semakin besar batch size dapat membantu mengurangi noise dalam perhitungan error, namun jumlah batch size yang besar tidak menjamin tingkat akurasi semakin membaik.

Setelah dilakukan beberapa skenario pengujian, didapatkan skenario terbaik dari berbagai parameter yang telah ditentukan. Parameter terbaik tersebut adalah menggunakan optimizer Adam dengan menggunakan nilai epoch 20, learning rate 0,0001 , dan nilai batch size 16. Hasil dari pelatihan dengan menggunakan parameter-parameter tersebut didapatkan nilai akurasi sebesar 0,9950 dan nilai loss sebesar 0,0223 . Grafik model akurasi dan model loss yang didapatkan dari hasil pelatihan ini ditunjukkan ada Gambar 3 dan 4 berikut ini.

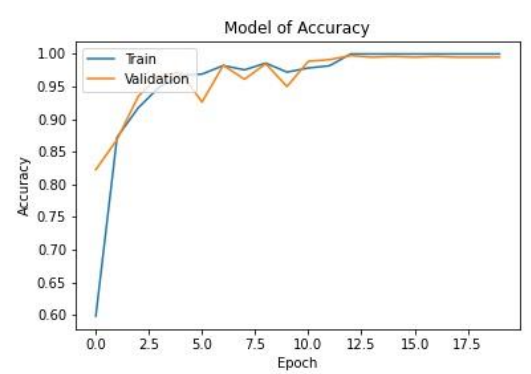

Gambar 3. Grafik Model Akurasi Skenario terbaik

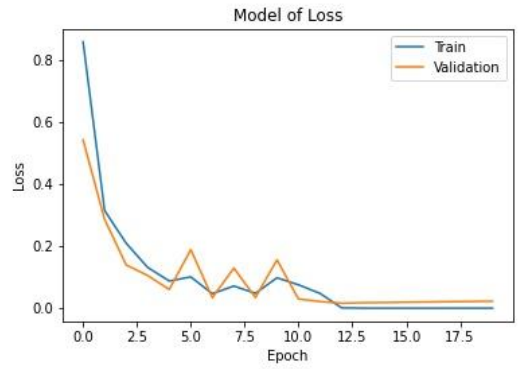

Gambar 4. Grafik Model Loss Skenario terbaik

Adapun tiga parameter pengukuran hasil performansi sistem lainnya, seperti nilai presisi, recall dan f1-score ditunjukkan dengan menggunakan nilai dari 0 sampai 1 , semakin dekat nilainya dengan angka 1 , maka semakin sedikit error yang terjadi. Skor detail dari masing-masing parameter pengukuran hasil performansi sistem tersebut ditunjukkan pada Tabel 6 berikut ini

Tabel 6. Tabel Performansi Sistem Skenario Terbaik

\begin{tabular}{ccccc}
\hline Kelas & Presisi & Recall & $\begin{array}{c}\text { F1- } \\
\text { score }\end{array}$ & $\begin{array}{c}\text { Jumlah } \\
\text { Gambar }\end{array}$ \\
\hline $\begin{array}{c}\text { Nevus } \\
\text { Pigmentos } \\
\text { us }\end{array}$ & 1.00 & 1.00 & 1.00 & 174 \\
\hline $\begin{array}{c}\text { Melanom } \\
\text { a }\end{array}$ & 0.99 & 1.00 & 0.99 & 206 \\
\hline $\begin{array}{c}\text { Dermatofi } \\
\text { broma }\end{array}$ & 1.00 & 0.99 & 0.99 & 206 \\
\hline $\begin{array}{c}\text { Squamous } \\
\text { Cell }\end{array}$ & 1.00 & 1.00 & 1.00 & 214 \\
$\begin{array}{c}\text { Carcinom } \\
\text { a }\end{array}$ & & & & \\
\hline Total & $\mathbf{1 . 0 0}$ & $\mathbf{1 . 0 0}$ & $\mathbf{1 . 0 0}$ & $\mathbf{8 0 0}$ \\
\hline
\end{tabular}

Selain itu, hasil pelatihan dapat dilihat dari confusion matrix yang dihasilkan, untuk mengetahui jumlah data yang berhasil dideteksi dengan 
benar maupun salah oleh sistem. Gambar 5 menunjukkan confusion matrix dari hasil performansi sistem dengan skenario terbaik.

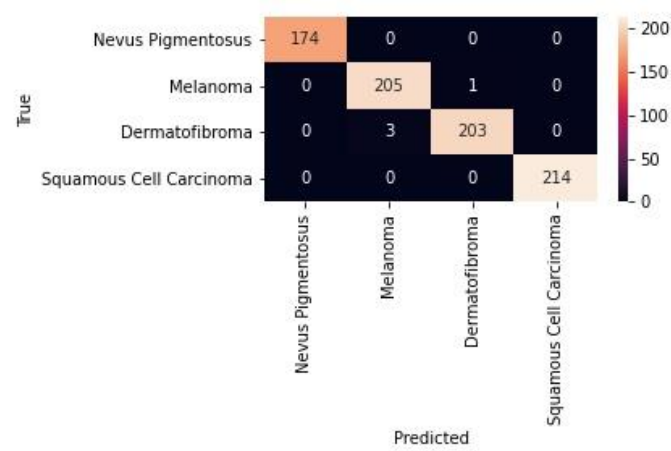

Gambar 5. Grafik Model Loss Skenario terbaik

Gambar 5 menunjukkan bahwa dari 800 citra yang digunakan sebagai data validasi, sebanyak 796 citra berhasil dideteksi dengan benar sesuai kelasnya masing-masing, sedangkan 4 citra lainnya terdeteksi salah. Kesalahan deteksi terjadi pada satu citra melanoma yang terdeteksi sebagai dermatofibroma dan tiga citra dermatofibroma terdeteksi sebagai melanoma.

\section{SIMPULAN}

Sistem klasifikasi yang dibuat dapat digunakan untuk mendeteksi kanker kulit dan membantu mengurangi resiko keterlambatan diagnosis dini pada 4 kelas kanker kulit yaitu dermatofibroma, melanoma, nevus pigmentosus, dan squamous cell carcinoma dengan performansi sistem yaitu tingkat akurasi sebesar 99,50\%, nilai presisi dan recall sebesar 99,75\%, nilai f1-score sebesar 99,50\%, dan nilai loss sebesar 0,0223. Parameter terbaik yang digunakan dalam sistem klasifikasi yang dibuat yaitu menggunakan resize $64 \times 64$ piksel pada saat pre-processing, menggunakan optimizer Adam, learning rate 0,0001, epoch 20, dan batch size 16.

Untuk penelitian lebih lanjut, disarankan untuk menambahkan jumlah kelas kanker kulit yang dideteksi, dan mencoba sistem klasifikasi dengan model dan arsitektur lainnya.

\section{DAFTAR PUSTAKA}

I. C. C. Community, "Sekilas Kanker Kulit," Indonesia Cancer Care Community, [Online]. Available: https://iccc.id/sekilas-kanker-kulit. [Accessed 5 Agustus 2021].

Foeady, A. Z. "Sistem Klasifikasi Kanker Kulit Berdasarkan Data Citra Dermoscopic dengan Menggunakan Metode Deep Extreme Learning Machine," UIN Sunan Ampel, p. 1, 2019.

Munthe, T. L. D. "Klasifikasi Citra Kanker Kulit Berdasarkan Tingkat Keganasan Kanker pada Melanosit Menggunakan Deep Convolutional Neural Network," Universitas Sumatera Utara, p. 74, 2018.

Wahaninggar, K. "Klasifikasi Citra Kanker Kulit Melanoma Menggunakan Metode Support Vector Machine (SVM)," Institute Teknologi Surabaya, p. 73, 2016.

Mentari, M. "Deteksi Kanker Kulit Melanoma dengan Linear Discriminant Analysis-Fuzzy kNearest Neigbhour Lp-Norm," Universitas Brawijaya, p. 6, 2016.

Khalid M. Hosny, M. A. K. a. M. M. F. "Skin Cancer Classification using Deep Learning and Transfer," IEEE, p. 4, 2018.

Md Zahangir Alom, T. M. T. C. Y. S. W. P. S. M. S. N. B. C. V. E. A. A. S. A. V. K. A. "The History Began from AlexNet: A Comprehensive Survey on Deep Learning Approaches," Cornell University, 2018.

D. H. Dr Amanda Oakley, "Dermatofibroma," January 2016. Diunduh di https://dermnetnz.org/topics/dermatofibro ma/ tanggal 24 November 2020.

M. B. S. D. S. S. Mousumi Roy Bandyopadhyay, "Dermatofibroma: Atypical Presentations. 
Indian Journal of Dermatology," 15 January 2016. Diunduh di https://www.eijd.org/text.asp?2016/61/1/121/174131 tanggal 15 April 2021.

Suriany, "Hubungan Tumor-Infiltrating Lymphocytes (TILs) Histologi Karsinoma Sel Skuamosa Kulit," Universitas Sumatera Utara, p. 17, 2019.

Delila Tsaniyah R, A. a. F. "Prevalensi dan Gambaran Histopatologi Nevus Pigmentosus di Bagian Patologi Anatomi Rumah Sakit Dr. Mohammad Hoesin Palembang," JanuariDesember 2009-2013.

Ennok Nisa Islamiati, S. N. I. M. K. D. H. I. M. N. "Karakteristik Nevus Pigmentosus berdasar atas Gambaran Histopatologi," Jurnal Integrasi Kesehatan \& Sains, vol. 1, 2019.

Burger W, M. J. B. "Digital Image Processing: An Algorithmic Introduction using Java, Texts in Computer Science," ISBN 978-1-84628-3796. Springer-Verlag London, 2008.

Saputra, R. A. P. K. A. N. R. a. W. S. A. D. I. S. "Pelacakan dan deteksi wajah menggunakan video langsung pada webcam," Telematika, vol. 10, pp. 50-59, 2017.

Setiaji, A. "Deep Learning : Activation Function," 01 September 2018.

Agarap, A. F. "Deep Learning using Rectified Linear Units (ReLU)," pp. 2-8, 2018.

Kim, P. MATLAB Deep Learning : With Machine Learning, Neural Networks and Artificial Intelligence, 2017.

Karpathy, Intoduction to Convolutional Neural Networks, 2018.

Sofia, N. "Convolutional Neural Network," 9 June 2018.

Bilogur, A. "Keras Optimizers," Kaggle, 2018. Diunduh "di https://www.kaggle.com/residentmario/kera s-optimizers tanggal 12 Agustus 2021.

Munir, R. Pengolahan Citra Digital, Informatika Bandung, 2004.
"The International Skin Imaging Collaboration," Diunduh di https://www.isicarchive.com/ tanggal 24 November 2020. 